\title{
Isolation and characterisation of the ovine gastrin-releasing peptide gene; abundant expression in the pregnant uterus and selective expression in fetal tissues
}

\author{
J C Whitley, C Moore, A S Giraud ${ }^{\mathbf{1}}$ and A Shulkes \\ University of Melbourne Department of Surgery, Austin and Repatriation Medical Centre, Austin Campus, Heidelberg, Victoria 3084, Australia \\ ${ }^{1}$ University of Melbourne Department of Medicine, Western Hospital, Footscray, Victoria, Australia \\ (Requests for offprints should be addressed to A Shulkes; Email: aas@unimelb.edu.au) \\ (J C Whitley is now at the Victorian Institute of Animal Sciences, Attwood, Victoria 3049, Australia) \\ (C Moore is now at the School of Dental Science, University of Melbourne, Melbourne, Victoria 3000, Australia)
}

\begin{abstract}
High concentrations of a peptide related to gastrinreleasing peptide (GRP) are produced in the uteroplacental unit of the human and sheep and secreted into the general circulation. This suggests an endocrine role in addition to its role as a neurotransmitter/neuromodulator. The GRP is larger than the previously described form GRP(1-27) but it is not known whether the larger form is the product of a related GRP-like gene or differences in post-translational processing. We have therefore cloned the gene for the sheep homologue of the GRP gene and determined its distribution. Only a single GRP gene was found in the sheep. This had a similar organisation to the human GRP gene with three exons and two introns. The larger form of GRP in the pregnant endometrium therefore appears to be the result of an alteration in processing
\end{abstract}

of the GRP prohormone. The expression of GRP mRNA in the pregnant uterus was extraordinarily high comprising one-third of all mRNA synthesised by the pregnant endometrium. As the endometrial GRP mRNA arises solely from the glandular epithelium, the localised synthesis of GRP mRNA would be far higher. GRP mRNA was expressed in a wide variety of fetal tissues (fundus, colon, jejunum, ileum, duodenum, kidney, adrenal, lung, heart and pancreas) with a corresponding presence of GRP immunoreactivity. The expression of GRP in the fetal lung was biphasic with peaks at mid-term and near parturition but none in the adult supporting the concept of a specific developmental role of GRP in the lung.

Journal of Endocrinology (2002) 175, 447-457

\section{Introduction}

A novel endocrine role for gastrin-releasing peptide (GRP) was proposed several years ago with the discovery of high levels of GRP immunoreactivity in the peripheral circulation and uteroplacental unit of pregnant ewes (Giraud et al. 1993, 1994, Fraser et al. 1994). Previous to this observation, GRP was thought to act mainly as a neurotransmitter and be localised almost exclusively to neurons and neuroendocrine cells (Bunnett 1994). Further investigation of the GRP immunoreactivity in the pregnant ovine uterus showed that the protein was significantly larger than the known biologically active forms GRP(1-27) and the decapeptide GRP(18-27) (Giraud et al. 1996). A similar GRP related molecule was found in the pregnant human (Whitley et al. 1996). However it is not known whether this larger form is the product of a related GRP-like gene, alternative GRP mRNA transcripts or differences in post-translational processing.
Quantification of the expression of endometrial GRP is of interest because we have demonstrated that GRP in the ovine endometrium is a tightly regulated process with increases in GRP mRNA during the ovine oestrous cycle (24-fold) and early pregnancy (13-fold between days 17 and 20) (Whitley et al. 1998) while both GRP mRNA and peptide expression are reduced following the administration of oestrogen and progesterone (Whitley et al. 2000). Our initial studies suggested that in the pregnant uterus, the proportion of mRNA that is GRP was extraordinarily high and may be a potential explanation for the excess of large molecular weight forms. We have therefore quantified the proportion of poly $(\mathrm{A})+\mathrm{RNA}$ that is GRP mRNA in the late term endometrium by comparison to synthetic GRP mRNA standards and Northern analysis with a GRP antisense riboprobe.

While the endometrial glands appear to be the major source of the circulating GRP-like molecule as demonstrated by in situ hybridisation and radioimmunoassay (Whitley et al. 1998), GRP-like peptides may also be 
synthesised in other tissues of the uteroplacental unit and act locally. Thus in this study we have also analysed expression of the GRP gene in a panel of fetal ovine tissues in late pregnancy. Finally we have examined the ontogeny of GRP mRNA expression in the fetal ovine lung to determine whether the expression of GRP mRNA in some adult lung cancers (Cuttitta et al. 1985) is a recapitulation of fetal expression.

\section{Materials and Methods}

Construction and screening of ovine endometrial $\mathrm{CDNA}$ library

Human GRP cDNA (kindly provided by J Battey, NIHCD, NIH) was labelled with $\alpha-\left[{ }^{32} \mathrm{P}\right]$ dATP using a random primer labelling system (rediprime II, Amersham Pharmacia Biotech, Castle Hill, NSW, Australia) and used to screen approximately $2 \times 10^{4}$ plaques of an ovine late term endometrium cDNA library prepared in phage $\lambda$ gt 11 as per manufacturer's instructions (Amersham Pharmacia Biotech). Putative clones were selected and rescreened until individual plaques were isolated. Phage DNA was purified for three separate clones and the cDNA insert amplified using $\lambda \mathrm{gt} 11$ forward and reverse primers and the proof reading Taq polymerase Pfu prior to cloning into plasmid pBS SKII (Stratagene, La Jolla, CA, USA) and determination of nucleotide sequence by automated DNA sequencing (ABI Prism 373 DNA sequencer, Perkin-Elmer, Foster City, CA, USA) with BigDye terminator chemistry and scanning laser detection.

\section{Screening of ovine genomic DNA library}

Approximately $5 \times 10^{5}$ recombinant $\lambda$ EMBL3 bacteriophages representing a library of EcoRI fragments of sheep genomic DNA (supplied by Dr Louise Baker, Department of Veterinary Science, University of Melbourne) were screened by hybridisation with radiolabelled ovine GRP cDNA (isolated above) as described previously (Whitley et al. 1999). Following four rounds of screening, two individual positive plaques were isolated and phage DNA purified. Restriction maps were constructed by Southern hybridisation using fragments of ovine GRP cDNA. Exons 1 and 2 were located on one genomic fragment (phage denoted $\lambda$ GRP7) and exon 3 on the other (phage denoted $\lambda$ GRP8). Appropriate restriction fragments encompassing individual exons were subcloned and the nucleotide sequence determined as described above.

\section{Southern hybridisation of ovine genomic fragments}

Ovine genomic DNA was prepared from white blood cells (Ausubel et al. 2000) and $10 \mu \mathrm{g}$ subjected to restriction endonuclease digestion with BamHI, EcoRI or HindIII. Fragments were separated by $0.7 \%$ agarose gel electrophoresis prior to vacuum transfer (VacuGene, LKB/AMRAD, Kew, Victoria, Australia) in $0.4 \mathrm{M}$ $\mathrm{NaOH}$ to charged nylon membrane (Hybond $\mathrm{N}+$; Amersham Pharmacia Biotech). Fragments with homology to the GRP cDNA were detected by hybridisation at $42^{\circ} \mathrm{C}$ in cDNA hybridisation buffer $(50 \%$ formamide, $5 \times$ Denhardts solution, $5 \times$ SSC, $50 \mathrm{mM} \mathrm{Na}$ phosphate $\mathrm{pH} 6 \cdot 8,100 \mu \mathrm{g} / \mathrm{ml}$ denatured salmon sperm DNA and $1 \%$ SDS) for $16 \mathrm{~h}$ with radiolabelled ovine GRP cDNA as probe. Unbound probe was removed by two rinses in a buffer containing $0 \cdot 1 \times$ SSC, $0 \cdot 1 \%$ SDS and two successive washes at $60{ }^{\circ} \mathrm{C}$ in the same buffer and responsive fragments visualised by autoradiography to X-ray film (XAR-5, Kodak, Integrated Sciences, East Kew, Victoria, Australia).

\section{Analysis of $m R N A$ expression}

Several methods were used for detection of mRNA expression depending on the relative abundance of GRP in the tissues analysed. For all samples, ovine tissue was removed soon after killing (all procedures were approved by the Animal Ethics Committee of the Austin and Repatriation Medical Centre) and stored frozen at $-70{ }^{\circ} \mathrm{C}$.

\section{Preparation of total RNA}

Total RNA was prepared from $200 \mathrm{mg}$ frozen tissue using Trizol reagent (Gibco-BRL, Mulgrave, Victoria, Australia). Contaminating endogenous RNases were destroyed by treatment with $40 \mu \mathrm{g}$ proteinase K (Sigma Chemical Co., St Louis, MO, USA) in a reaction buffer consisting of $0 \cdot 1 \mathrm{M}$ Tris-Cl, $\mathrm{pH} 7 \cdot 8,0.05 \mathrm{M}$ EDTA, $1 \%$ SDS for $30 \mathrm{~min}$ at $50{ }^{\circ} \mathrm{C}$. Proteinase $\mathrm{K}$ was removed by extraction with an equal volume of phenol:chloroform: isoamyl alcohol (25:24:1) and the RNA precipitated with $0.3 \mathrm{M} \mathrm{Na}$ acetate, $\mathrm{pH} 5$ and one volume of isopropanol as per standard procedures (Ausubel et al. 2000) and resuspended in sterile water. A $5 \mu \mathrm{g}$ sample of each RNA was subjected to denaturing electrophoresis through low formaldehyde containing agarose as previously described (Whitley et al. 2000) to check integrity and concentration estimation of the prepared RNA.

\section{Northern analysis}

Samples of total RNA were separated by agarose gel electrophoresis (as above) before vacuum transfer in $20 \times$ SSC $300 \mathrm{mM} \mathrm{NaCl}, 30 \mathrm{mM}$ sodium citrate) for $4 \mathrm{~h}$ to nylon membrane (Hybond $\mathrm{N}+$ ). Following transfer, the membrane was rinsed briefly in $2 \times$ SSC and air dried before fixing the nucleic acids to the membrane by treatment with u.v. light (Ultraviolet Cross-linker, Amersham Pharmacia Biotech) using the manufacturer's settings. Labelled riboprobes for GRP and GAPDH were 
prepared and purified essentially as described previously (Whitley et al. 1998) using the MAXIscript kit (Ambion, Austin, TX, USA) including $0 \cdot 85 \mu \mathrm{M}\left[{ }^{32} \mathrm{P}\right] \mathrm{UTP}$ and $2 \cdot 15 \mu \mathrm{M}$ unlabelled UTP. Recombinant plasmids containing ovine GRP cDNA (isolated above) or ovine GAPDH cDNA (exons A-H, a generous gift from Dr Louise Baker, Department of Veterinary Science, University of Melbourne) were digested with appropriate restriction enzymes to yield labelled antisense cRNA molecules of approximately 230 and 290 nucleotides (nt) respectively. Riboprobes were added $\left(5 \times 10^{5}\right.$ c.p.m. $\left./ \mathrm{ml}\right)$ to membranes sandwiched between two sheets of Whatman No. 1 filter paper that had been prehybridised for $16 \mathrm{~h}$ at $68^{\circ} \mathrm{C}$ in RNA-RNA hybridisation buffer $(55 \%$ formamide, $5 \times$ Denhardts solution, $2 \times \mathrm{SSC}, 50 \mathrm{mM} \mathrm{Na}$ phosphate $\mathrm{pH} 6 \cdot 8,100 \mu \mathrm{g} / \mathrm{ml}$ denatured salmon sperm DNA, $100 \mu \mathrm{g} / \mathrm{ml}$ E. coli tRNA and 1\% SDS). Following hybridisation at $68{ }^{\circ} \mathrm{C}$ for $24 \mathrm{~h}$, membranes were briefly rinsed twice in $0 \cdot 1 \times \mathrm{SSC}, 0 \cdot 1 \% \mathrm{SDS}$ and washed for $15 \mathrm{~min}$ at $68^{\circ} \mathrm{C}$ in the same solution. GRP or GAPDH mRNA was detected following autoradiography at $-70{ }^{\circ} \mathrm{C}$ using XAR-5 film and two intensifying screens.

\section{$R T-P C R$}

The methods used have been described previously (Whitley et al. 2000) and are only summarised here. Prior to cDNA preparation for RT-PCR, poly(A)+ RNA was prepared from $75 \mu \mathrm{g}$ total RNA using $1 \mathrm{mg}$ oligo dT-linked magnetic beads according to the manufacturer's instructions (Dynal, Clifton Hill, Victoria, Australia). Approximately $100 \mathrm{ng}$ poly(A)+ RNA and $4 \mathrm{ng} \mathrm{pdN}_{6}$ were used for cDNA synthesis with Superscript reverse transcriptase according to the manufacturer's instructions (GibcoBRL, Life Technologies, Mulgrave, Victoria, Australia). A portion of prepared cDNA $(1 / 20)$ was used in PCR for ovine GRP and ovine $\beta$-actin using oligonucleotide primers and conditions as described previously (Whitley et al. 2000). Products (1/5) were taken at the completion of PCR (40 cycles) and visualised by agarose gel electrophoresis and/or Southern hybridisation using oligonucleotide probes complementary to sequences located between primers.

\section{Quantitative determination of GRP $m R N A$ abundance}

Synthesis of GRP mRNA Sense GRP mRNA was synthesised from linearised plasmid DNA (ovine GRP cDNA inserted into pGEM3Zf+) as template and T7 polymerase according to the manufacturer's instructions (MEGAscript kit, Ambion, Austin, TX, USA). Protein was removed by extraction of the reaction mix with one volume of phenol:chloroform:isoamyl alcohol (25:24:1) followed by extraction with chloroform:isoamyl alcohol (24:1) and precipitation of the nucleic acid with one volume of isopropanol. A single product of 670 bases (corresponding to nts 8-678, GenBank Accession S75723) was visualised by denaturing polyacrylamide gel electrophoresis (5\% acrylamide, $8 \mathrm{M}$ urea).

Purification of poly(A) RNA Poly A+ RNA was purified from two different samples of approximately $900 \mu \mathrm{g}$ total RNA (prepared from late term ovine pregnant endometrium as described above) using biotinylated oligo dT and streptavidin linked magnetic beads according to the manufacturer's instructions (PolyATtract, Promega, Annandale, NSW, Australia). Products of the first round of purification were subject to a second round of poly(A)+ purification to ensure removal of all ribosomal RNA molecules. Quality and quantity of double purified poly(A)+ RNA were assessed by denaturing formaldehyde agarose gel electrophoresis and spectrophotometry (GeneQuant Spectrophotometer; LKB/AMRAD) respectively.

Slot blot hybridisation The slot blot manifold was prepared and assembled according to the manufacturer's instructions (Schleicher and Schuell, Dassel, Germany). Twofold serial dilutions of synthetic GRP mRNA were performed in denaturing solution $(60 \%$ formamide, $2 \cdot 3 \mathrm{M}$ formaldehyde, $1 \cdot 2 \times$ MOPS Buffer, $0 \cdot 1 \mathrm{mg} / \mathrm{ml}$ tRNA) to give a range from 20000 to $0 \cdot 15 \mathrm{pg}$ synthetic GRP mRNA. Dilutions of poly(A)+ RNA were performed in denaturing solution to give 10000,1000 and $100 \mathrm{pg}$ RNA. RNA samples were heated at $65^{\circ} \mathrm{C}$ for $15 \mathrm{~min}$, placed on ice and four volumes of ice cold $20 \times$ SSC added to each sample prior to vacuum transfer to positively charged nylon membrane (Hybond $\mathrm{N}+$ ). Following two washes with $10 \times \mathrm{SSC}$, the slot blot apparatus was dissembled and the membrane allowed to dry at room temperature. Nucleic acid was u.v. fixed onto the membrane and baked at $80{ }^{\circ} \mathrm{C}$ for $30 \mathrm{~min}$. Sense GRP mRNA was detected by hybridisation with radiolabelled antisense GRP riboprobe $\left(5 \times 10^{5}\right.$ c.p.m. $\left./ \mathrm{ml}\right)$ as described above for Northern analysis and visualised after exposure to phosphor screens (Storm 840 Phosphoimager, Molecular Dynamics, Amersham Pharmacia Biotech) and quantified using ImageQuaNT software (Molecular Dynamics). Results were subject to linear regression analysis and the amount of GRP mRNA in the two samples of poly(A)+ RNA determined by reference to a standard curve of log phosphor imager units versus log $10 \mathrm{pg}$ sense GRP mRNA using SigmaPlot 5 software (SPSS, Chicago, IL, USA).

\section{Results}

Organisation of the ovine GRP gene

Figure 1 shows partial restriction maps of ovine genomic DNA encompassing exons 1, 2 and 3 of the GRP gene. 

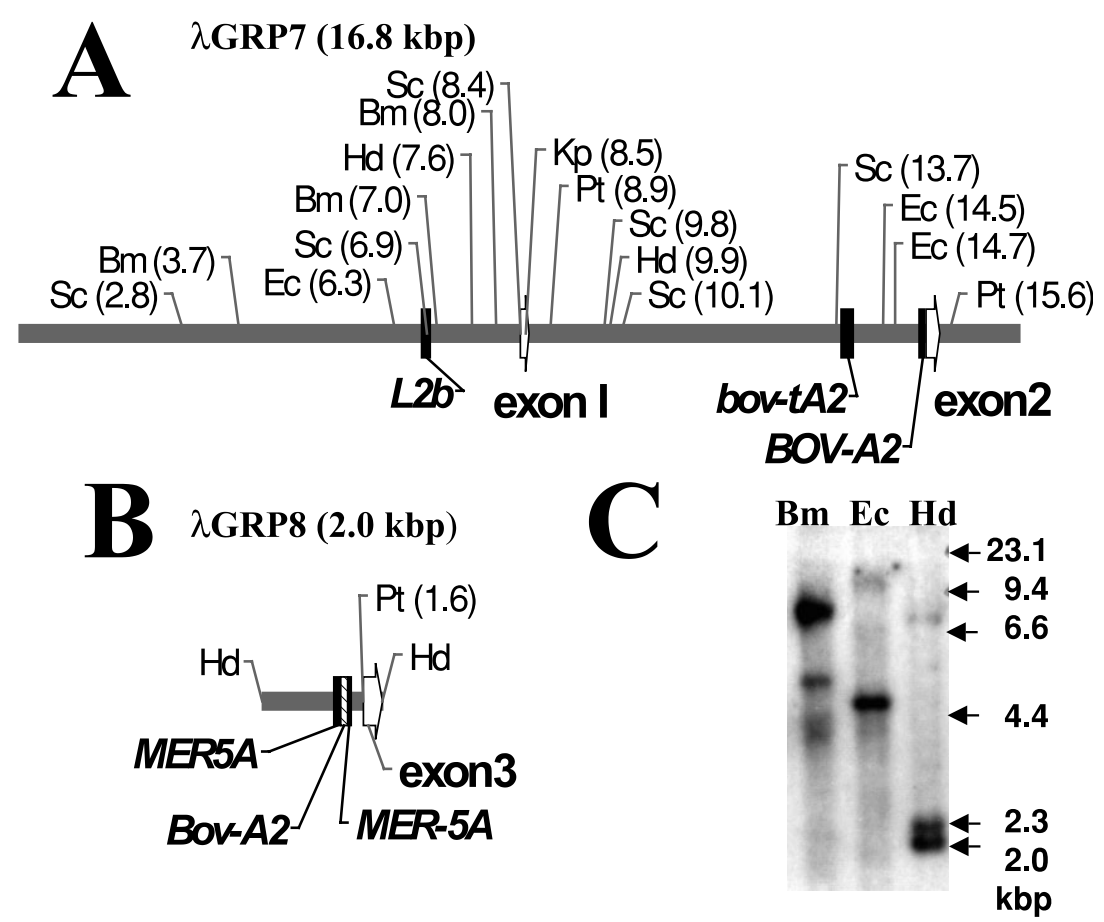

Figure 1 Genomic arrangement of the ovine GRP gene. Schematics for two ovine genomic DNA fragments cloned into $\lambda \mathrm{EMBL} 3$ and encompassing GRP exons 1, 2 and 3; $\lambda$ GRP7 (entire $17 \mathrm{kbp}$ insert) (A) and $\lambda$ GRP8 (2.0 kbp Hindlll subfragment) (B). The positions of all restriction sites for BamHI (Bm), EcoRI (Ec), HindIII (Hd), Sacl (Sc) and some restriction sites for endonucleases $\mathrm{Kpnl}(\mathrm{Kp})$ and $\mathrm{Pstl}(\mathrm{Pt})$ are shown above. The position of exons and repeat sequences are shown below. Maps were constructed using the Redasoft Plasmid 1.1 program (www.redasoft.com). (C) Southern hybridisation of ovine genomic DNA restricted with endonucleases BamHI, EcoRI and HindIII and probed with radiolabelled ovine GRP cDNA.

Exons 1 and 2 are separated by $6 \cdot 7 \mathrm{kbp}$ and were isolated on a single recombinant phage (Fig. 1A) whereas exon 3 was contained in a $2 \cdot 0 \mathrm{kbp}$ HindIII fragment isolated from a separate recombinant phage of approximate total size $16.5 \mathrm{kbp}$ (Fig. 1B). Southern hybridisation of ovine genomic fragments digested by endonucleases BamHI, EcoRI and HindIII with radiolabelled ovine GRP cDNA as probe revealed multiple responsive fragments (Fig. 1C). Comparison of the HindIII responsive fragments to the isolated genomic fragments suggested the presence of a single GRP gene, i.e. the $2 \cdot 3$ and $2.0 \mathrm{kbp}$ bands represent the HindIII fragments possessing exons 1 and 3 respectively while exon 2 is located within a fragment that must be larger than $6.9 \mathrm{kbp}$ which is seen as a faint band at approximately $7 \cdot 0 \mathrm{kbp}$ on Southern hybridisation (Fig. 1C).

\section{Nucleotide sequence of the ovine GRP gene and} cDNA molecules

The nucleotide sequence of the ovine GRP gene was determined (Fig. 2) and compared with the known ovine GRP cDNA sequence (Xiao et al. 1996, GenBank Accession S75723). Several discrepancies were observed at the extreme 5' UTR (shown in Fig. 2). Similarly, two of the three cDNA molecules isolated in this study also

\footnotetext{
Figure 2 Nucleotide sequence of the sheep GRP gene. Coding sequence for all 3 exons is shown (upper case) along with 2214 nt of the promoter, all of the $5^{\prime}$ UTR, partial introns 1 and 2, and part of the $3^{\prime}$ UTR. Numbering is with reference to the adenosine of translation start codon ATG as +1 . Intron sequence is not included in the number shown above. The promoter TATAA sequence is boxed and three predicted transcription initiation start sites denoted P1, P2 and P3. A cAMP responsive element (CRE) is boxed. The extreme 5' UTR of four GRP cDNA molecules are aligned underneath the genomic DNA sequence and labelled S75723 (Xiao et al. 1996) E14, E2 and E5 (isolated in this study). The amino acid sequence is shown in single letter code below the nucleotide sequence. Amino acids corresponding to biologically active GRP1-27 and to its prohormone processing site are shown in bold and underlined respectively. The stop codon TGA is indicated $\left({ }^{*}\right)$. A putative polyadenylation site in the $3^{\prime} \mathrm{UTR}$ is shown in bold. A single nucleotide difference to the published cDNA sequence is shown at +642 .
} 
-2214 atcaaggcet gtgggtgcat cgattctttt gggaagcagc taaagggtta agattccatt taagaaagat -2144 tagatgaaat gttccccaag tggggaattc aatgaaggag taccctaatt tgtgccacag gataagaggg -2074 tgcaatgccc cactgagcca aagcaagtga cgtatctaag ccgaagacgg ggtgcagaaa gcctgtagac -2004 caggggttta gagcagaagc tgaaatgaac agaggagcce aggtgcctct tggectgtaa cagacctaag -1934 aaagagtggc ctgcctgaat tagctctttc tgtagaactg ttcccacatt ttattatatt tacagttgct -1864 ttcccttggt ctcatagtgg aaaaaacttt attaaaagat tctaaaataa tcttgattaa actaagggga -1794 aaggatattt ttctatcact taatctggag agagaaaggt ttaatgcccc tctgaaggca ccggttgcag -1724 aaagcattta gatgcgagca tttctcaggt tagctgttca ttcatcaaac agctgctgtg tgccactggg -1654 tccaggctct ttgcaggecc acaggggaat gagaccctgt ccctgagttc aggegagctc cccaccaagt -1584 gggaggcagt gagcctacaa atggtcacct gatggtggaa catttgctgc ctaataagca gagcctggga -1514 acccagaggg atgaagtcaa agcccatgtc ggctttcccc ctcaattttc acttgagggc attccctcag - 1444 gatcctatta ctctgttgcc tggctaataa tggtgctctt gaaattagtg cttgttttaa ccttctagcc - 1374 agacacatgc atggaaatac tcttccaagc tcaagaacac tcagtcatgg gacatgcaca tgtcaccatc -1304 tgaggctggc tcaggtgcac tgggccacga gataaagaat atggtttcaa cttaattggt atcaacggcc - 1234 agtattgaca cggaacacca gcagggaccc accagcgagt gattcaccag cacttggtga ggaacaggca -1164 cgcaggagcg cagcaacaca cccccagctc tggcagccga atcgtgggca gcagcaccct ccacgcttcc -1094 agtcgctgcg gcacggctat ggcgcccacc cgctttgtat ccatggcatt gagaatctcg ggagttgagc

-1024 cggtggccct tcctcatctc cgagaacaga aggagcagag caaagatgcc cagccctaga ggagtgtgta

-954 aacagcagct gagggacagt ttgcgccgtc tggtaggcgc agcctaggaa accagcatag aagcttcttc

-884 cattaggcgg acgctgatga agggaaccag gagcgtagta aactgttgc tagttccatc acattacacg

-814 tctttcccgc tccagcttcc attgcacctc acgggcaggg acggaaacc caggtcgggt gagggtattt

-744 gctggaggcg gtgaaccggc gggggttagg ggcgctctgc aggaggcagg caaaggtctg gagtttcgcg

-674 ggctaggacg cgaggaggga ggtggccccc agagcggaaa ggtctgagaa tcagaagtgc tttgcaattc

-604 gggetccaat cccctccggc aaagctcggc ctaaaaacat ccatcctccg tgttcatccc tctctacaac

-534 ccgcgctccg ccgcacctct cgcccetggg gtcgggcgge cgcgtccttg ctccccettg ctggatccga

-464 aggcagctag ccaggaggcg ccctggccga gctgcgaaag gagggcttcg ctacattgtg ctggagcgac

-394 ggcgtcgagg gtgggaagga gtccagtgtg gggtggcggg cgggtctacg cgggaaagag agaggcgcgc

-324 ggggaacacc cggcctttc acccctggge gggaagatgg atggttttcg gaggccgtgg tcccagcgec

CRE

-254 ccggctctcg ccacaggg e acgtcalgagc getcggggec gcggcggagg agcgecccce ccgeccgcgc

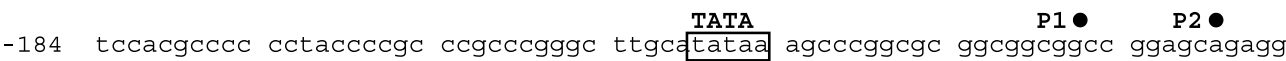

\section{P3•}

-114 cgggcggegg cggcggeget tetgcgagct cegggtcctg ggcttgcetc cgcggggaga acgcgetttc

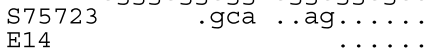

$\begin{array}{lll}\mathrm{E} 14 & \ldots . & \ldots \ldots\end{array}$

E5

...............

-44 cgcccagcet atccgeggeg ctccgggege ctcccgecgg tacCATGCGC AGCCGCGAGG TCTCGCTCGT

+27 CCTGCTGGCC CTGGTCCTCT GCCCGGCGCC CCGGGGATCG GCCGCCCCGG TGACGGCTGG CAGAGCAGGC $\begin{array}{lllllllllllllllllllllllll}\text { L } & \text { L } & \text { A } & \text { L } & \text { V } & \text { L } & \text { C } & \text { P } & \text { A } & \text { P } & \text { R } & \text { G } & \text { S } & \text { A } & \text { A } & \text { P } & \text { V } & \text { T } & \text { A } & \text { G } & \text { R } & \text { A } & \text { G }\end{array}$

+97 GCGCTGGCCA AGATGTACAC GCGCGGCAAC CACTGGGCGG TCGgtgagtg tCCCgegege tcgagtcCCg $\begin{array}{lllllllllllllll}\text { A } & \text { L } & \text { A } & \text { K } & \text { M } & \text { Y } & \text { T } & \text { R } & \text { G } & \text { N } & \text { H } & \text { W } & \text { A } & \text { V }\end{array}$

gggggccagc.....intron $1(6.7 \mathrm{kbp}) \ldots \ldots \ldots$ ccttctccat tctgcttttg aacagGACAC G H

+146 TTAATGGGAA AAAAGAGTGT GGCAGAGTCC CCACAACTTC GTGAGGAGGA GAGCCTGAAG GAGCAGCTGA $\begin{array}{llllllllllllllllllllllll}\mathrm{L} & \text { M } & G & \mathrm{~K} & \mathrm{~K} & \mathrm{~S} & \mathrm{~V} & \mathrm{~A} & \mathrm{E} & \mathrm{S} & \mathrm{P} & \mathrm{Q} & \mathrm{L} & \mathrm{R} & \mathrm{E} & \mathrm{E} & \mathrm{E} & \mathrm{S} & \mathrm{L} & \mathrm{K} & \mathrm{E} & \mathrm{Q} & \mathrm{L}\end{array}$

+216 GGGAGTACGC CCAGTGGGAA GAAGCGACCA GGAACTTGCT AAGCCTCCTA CAAGCAAAGg TGGCCCAAGg $\begin{array}{lllllllllllllllllllllllllllll}R & E & Y & A & Q & W & E & E & A & T & R & N & L & L & S & L & L & Q & A & K & V & A & Q & G\end{array}$

CCACCAGCCG CCTCGATGGg AGCCCCTGAg CATTCACCAG CCTGCCTGGg ATTCCAAGGA CGTCAGCAAC

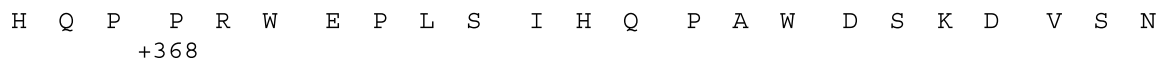

+356 TTCAAAGACT CAGgttcgag actcaagggt acagagaaca taccaggggg gtggaggtcg ggagaggtgg F $\quad$ K $\quad D \quad S$

getggggegg gggtggaagg.....intron $2 \ldots .$. ggactcttca ctgcagGTTC TCAGCGTGAA

+383 GGAGGGAACC CCCAGCTGTA CTGAcgatga caatagccge ctccctcaaa gaagcaaaac aaaaccctta $\begin{array}{llllllllllllll}G & G & N & P & Q & L & Y & *\end{array}$

agaaactgtg ttctacggge gtccgttcta ctggatcatc aacagatttc ctttgtgcaa aatacttaac tattcttgta cctttcaact ttgactaaag tcatgatttt caagcagcat cttctggttt gaacttgttt gctgtgaaaa attgtccata aagagtcttc taattaatgt tctttacatc taggccatct attagattcc agtccccaac ctgttaccag tcacaataaa agctt
9

Journal of Endocrinology (2002) 175, 447-457 


\begin{tabular}{|c|c|c|c|c|c|c|}
\hline & +1 & +18 & +27 & & +45 & \\
\hline sheep & APVT--AGRA & GALAKMYPRG & NHWAVGHLMG & KKSVAESPQL & - -REEESLKE & QLREYAQWEE \\
\hline human & V.LP- - . .GG & TV.T.... & $\ldots \ldots \ldots$ & ... TG. . SSV & $--S . R G \ldots Q$ & $\ldots \ldots$ IR . . \\
\hline rat & $\ldots$. STG . GG & TV. $\underset{\text { KXXXR }}{\ldots \ldots}$ & $s \ldots \ldots$ & ...TD.L.P. & $\begin{array}{r}\text { YAADRDG } \ldots \\
\text { KX }\end{array}$ & $\underset{\mathrm{XXR}}{\ldots . \mathrm{G} . \mathrm{IR} \ldots}$ \\
\hline sheep & ATTNLLSLLQ & AKVAQGHQPP & RWEPLSIHQP & AWDSKDVSNF & KDSGS-- - - - & $-------\mathrm{QRE}$ \\
\hline human & .A....G.IE & . . ENRN . . . . & QPKA. GNQ . . & S...E.S... & . . V. . KGKVG & RLSAPGS . . . \\
\hline rat & .A....G. E & . SRNRS . . . . & QDQ . . GSL . . & T..PE.G.Y. & S.AQNAKL.D & S. LQVLKGK. \\
\hline sheep & \multicolumn{6}{|l|}{ GGNPQLY - - } \\
\hline human & \multicolumn{6}{|l|}{ R. . . NQQ } \\
\hline & \multicolumn{6}{|l|}{ TAS - - - - } \\
\hline \multicolumn{7}{|c|}{$\begin{array}{l}\text { Figure } 3 \text { Alignment of mammalian proGRP amino acid sequences using the single letter code with identical } \\
\text { sequences denoted by dots. Shown is the sheep sequence determined in this study, human form I } \\
\text { (GenPept accession no. P07492) and rat (GenPept accession no. A40922). Numbering is for the sheep } \\
\text { sequence. Consensus sequence for GRP peptides and the prohormone processing site are written in bold. } \\
\text { The conserved motif KXXXR is shown below the aligned sequence. }\end{array}$} \\
\hline
\end{tabular}

diverged from the genomic sequence in this region (shown in Fig. 2). A single nucleotide difference to the published cDNA sequence was also observed in the 3'UTR at +642 (Fig. 2). For all molecules (genomic and four cDNA), there was no variation in the coding sequence (not shown). Intron-exon boundaries were inferred by alignment to the ovine GRP cDNAs and agreed with intron placement of the human GRP gene. All splice sites scored highly by computer analysis (CGG Nucleotide sequence analysis, program spl, http://dot.imgen.bcm.tmc.edu: 9331/gene-finder/gfb.htm).

The position of the ovine GRP gene promoter and transcription start site was inferred by comparison to cDNA molecules, human GRP gene promoter and by computational analysis of the genome sequence. Promoter prediction by neural network (http:/www-hgc.lbl.gov) of $3.6 \mathrm{kbp}$ sequence including exon 1 and $2 \cdot 2 \mathrm{kbp}$ upstream sequence returned four promoters with cut off scores above $0 \cdot 85$ which detects $0 \cdot 1-0 \cdot 4 \%$ false positives. Three of these were clustered around the cDNA start sites and are found 15, 26 and $45 \mathrm{nt}$ downstream from the TATA box (denoted P1, P2 and P3 respectively; Fig. 2). A consensus sequence for a cAMP responsive element (CRE) was found at -229 to -236 upstream from the ATG translation start site. The identical sequence AGACGTCA is found in a similar position in the human GRP gene promoter (GenBank Accession S73265, Nagalla \& Spindel 1994).

\section{Repeat sequences}

Several repeat sequences were identified using the RepeatMasker program (Smit AFA \& Green P at http:/ ftp.genome.washinton.edu/RM/RepeatMasker.html) and are denoted on the restriction maps (Fig. 1A and B). These include both human and ruminant specific elements. There is a long interspersed nuclear element (LINE), type L2b in the region upstream to exon 1, two ruminant specific short interspersed nuclear elements
(SINEs), types tA2 and A2 preceding exon 2 and another preceding exon 3 that interrupts a human MER5A type DNA element (Fig. 1A and B). Consistent with species relativity, the ovine sequences show 21-27\% divergence to the human sequences and 4 or $13 \%$ divergence to the bovine derived sequences. The presence of these repeat sequences is consistent with the observation that eukaryotic genomes comprise large amounts of repetitive DNA, some representing interspersed repeats derived from inactive copies of a wide variety of transposable elements (Jurka 1998).

\section{Alignment of mammalian proGRP molecules}

Figure 3 shows alignment of the proGRP molecules for three known mammalian species; sheep, human and rat. The endoplasmic reticulum signal sequence is cotranslationally cleaved and is not shown in this alignment. The amino acid sequence for toad proGRP is known (GenPept accession no. P29007) but is not included in this comparison as it is significantly different. Previous analysis of cDNA clones from a carcinoid lung tumour (Spindel et al. 1986) and small cell lung cancer cell line (Sausville et al. 1986) showed the existence of three distinct GRP mRNA transcripts arising from processing at alternative donor and acceptor splice sites at exons 2 and 3 respectively, of a single GRP gene. In Fig. 3 we have only included the product resulting from translation of human GRP mRNA form I as this form shows the highest homology to rat and sheep sequence and is the predominant form found in normal and neoplastic tissue (Spindel et al. 1987). The most extensive region of homology exists from +11 to +31 and encompasses the motif conserved for all gastrin-releasing peptides - WAVGHLM representing the C-terminal region of biologically active GRP1-27 and GRP18-27. Four conserved basic amino acids are observed at $+13,+17,+45$ and +49 (numbering refers to sheep sequence). Cleavage at Arg-17 is known to 


\section{ABCDEFGH I JKL + + -}

$\begin{array}{llllllllllllllllllllll}6.2 & 6.8 & 6.7 & 4.0 & 3.8 & 5.0 & 6.7 & 1.3 & \text { NM } & 0.9 & 3.9 & 1.8 & \text { NM NM }\end{array}$

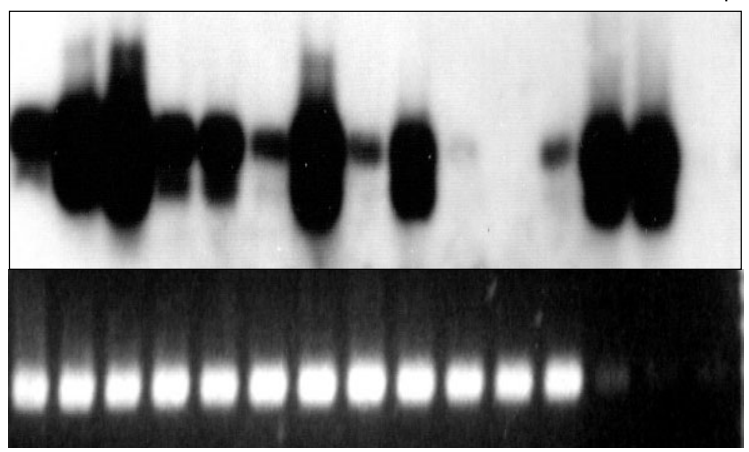

Figure 4 Expression of GRP mRNA (top panel) and $\beta$-actin mRNA (bottom panel) in a panel of ovine fetal tissues detected by RT-PCR. cDNA was prepared from jejunum (A), ileum (B), kidney $(C)$, duodenum $(D)$, fundus $(E)$, lung $(F)$, colon $(G)$, heart $(H)$, adrenal $(\mathrm{I})$, liver $(\mathrm{J})$, antrum $(\mathrm{K})$ and pancreas $(\mathrm{L})$. cDNA from adult pituitary ( $1 / 5$ dilution) was used as positive controls $(+)$. A water control was also included (-). Products for GRP were detected by Southern hybridisation using a gene specific oligonucleotide probe. Products for $\beta$-actin were detected by ethidium bromide staining. GRP-ir (pmol/g) for matching tissue samples are shown above the top panel.

yield GRP18-27. Interestingly these four conserved basic amino acids pair to form two copies of the motif KXXXR.

\section{GRP $m R N A$ expression in fetal sheep tissues}

GRP mRNA expression was examined in a variety of fetal tissues isolated from a single animal (120 days gestation) using the sensitivity afforded by semi-quantitative RTPCR (Fig. 4). Synthesis of GRP mRNA was detected in a wide range of tissues including kidney, adrenal, lung and parts of the gastrointestinal tract (duodenum, jejunum, ileum, fundus and colon). Some GRP mRNA was detected in fetal liver and pancreas but none in stomach antrum. RIA of matching tissue samples (method described in Whitley et al. 1998) revealed GRP-ir in all tissues tested (adrenal gland was not assayed) and in amounts roughly correlating with GRP mRNA detection (Fig. 4). For example GRP-ir was highest in ileum (B), kidney $(\mathrm{C})$ and colon $(\mathrm{G})(6 \cdot 8,6 \cdot 7$ and $6.7 \mathrm{pmol} / \mathrm{g})$ where
GRP mRNA abundance was also high, and lowest in heart $(\mathrm{H})$, liver $(\mathrm{J})$ and pancreas $(\mathrm{L})(1.3,0.9$ and $1.8 \mathrm{pmol} / \mathrm{g})$ where GRP mRNA abundance was low. Two exceptions to this pattern were fetal lung (F) $(5 \mathrm{pmol} / \mathrm{g})$ and antrum $(\mathrm{K})(3.9 \mathrm{pmol} / \mathrm{g})$ where GRP mRNA synthesis was very low and undetectable respectively. The ontogeny of expression of GRP mRNA in the fetal lung was examined by Northern analysis modified for high sensitivity and maximum detection (Fig. 5). GRP mRNA abundance was detected in similar amounts in fetal lung at days 40 (not shown), 60 and 80 but not at days 100 and 120. Fetal lung obtained at days 140 and 145 gestation had the most GRP mRNA abundance whilst the adult lung had none under these experimental conditions.

Examination and quantification of GRP $m R N A$ abundance in the pregnant endometrium

Northern analysis using poly(A)+ RNA isolated from adult tissues confirmed previous observations of high expression in ovine pregnant endometrium and myometrium (Whitley et al. 1998), lower expression in nonpregnant endometrium and myometrium and the absence or extremely low expression of GRP mRNA in hypothalamus, testes and amnion (Fig. 6). Inspection of the agarose gel following staining with ethidium bromide revealed a smear of poly(A)+ material in all lanes (as expected) and three distinct bands (Fig. 6, top, lane E) in the lanes representing poly $(\mathrm{A})+$ RNA prepared from late term pregnant endometrium and myometrium (Fig. 6). The band of lowest mobility represents residual $18 \mathrm{~S}$ rRNA and the band of highest mobility corresponds in size to GRP mRNA at approximately $900 \mathrm{nt}$, as identified by Northern analysis (Fig. 6, middle). A third abundant mRNA of approximately $1500 \mathrm{nt}$ was also observed but is so far unidentified. This observation (and many similar) suggested that GRP mRNA is a highly abundant transcript in ovine pregnant endometrium and myometrium. The proportion of poly (A)+ RNA that is GRP mRNA was determined by comparing the amount of GRP mRNA in double purified poly(A)+ RNA isolated from two separate samples of late term pregnant ovine endometrium to a standard curve of known amounts of synthetic sense GRP cRNA (Fig. 7A and B). GRP

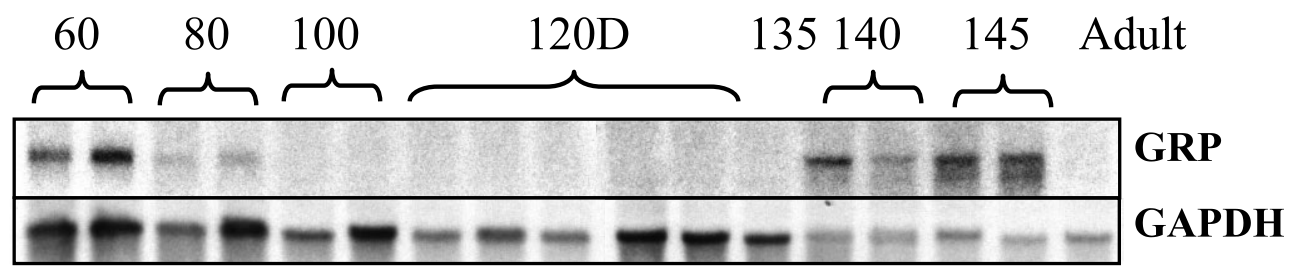

Figure 5 Northern analysis showing the ontogeny of GRP mRNA expression (top panel) compared with the expression of GAPDH mRNA (bottom panel) in fetal lung taken at different stages of gestation (as indicated) and adult lung. 


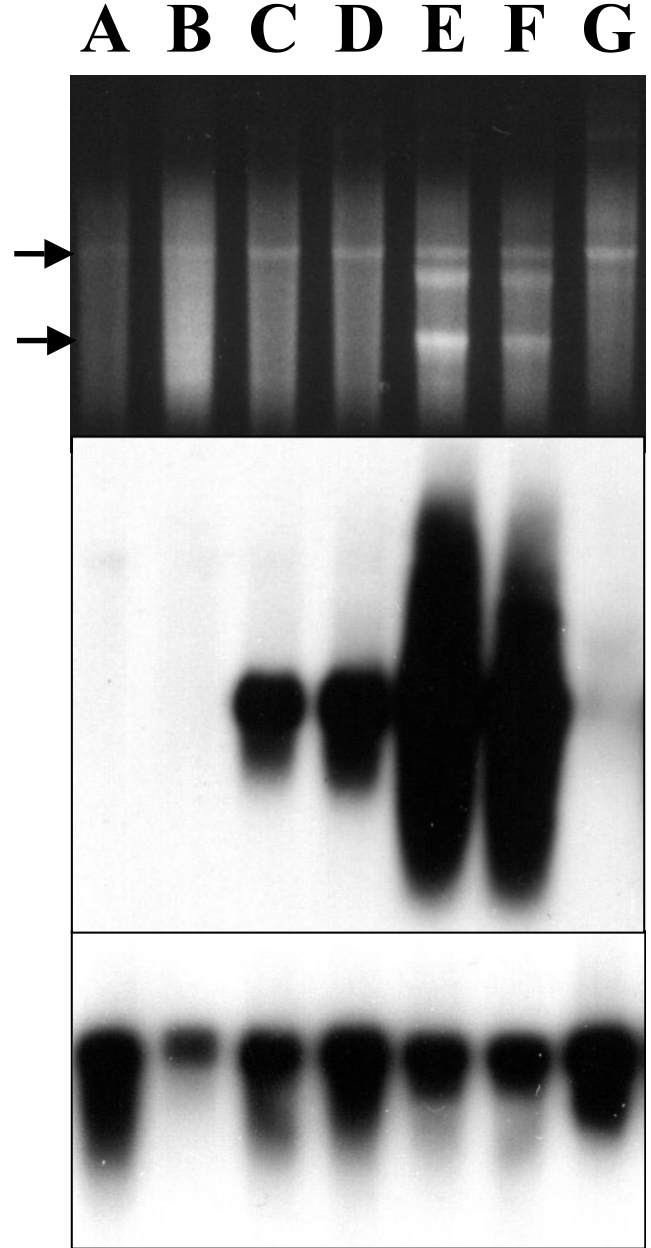

Figure 6 Northern analysis of GRP mRNA in sheep utero-placental tissues, hypothalamus and testes. Approximately $5 \mu \mathrm{g}$ polyA+ RNA isolated from hypothalamus $(A)$, testes $(B)$, non-pregnant endometrium (C), non-pregnant myometrium (D), pregnant endometrium (E), pregnant myometrium (F) and amnion (G). Arrows indicate residual $18 \mathrm{~S}$ rRNA (top) and GRP mRNA (bottom). The middle and bottom panels show the results of Northern analysis for GRP and GAPDH mRNA respectively.

mRNA was visualised by Northern hybridisation with radiolabelled antisense GRP riboprobe and phosphor imaging. Linearity of response was observed over two orders of magnitude, from 1.22 to $1250 \mathrm{pg}$ GRP cRNA (Fig. 7C). Linear regression analysis of these points enabled determination of the amount of GRP mRNA in 100 and $1000 \mathrm{pg}$ double purified poly(A)+ RNA from two separate samples of late term pregnant endometrium (the $10000 \mathrm{pg}$ point was outside the linear range). For sample 1 this was found to be 37 and 322 pg respectively and for sample 2 this was found to be 22 and $230 \mathrm{pg}$ respectively. Thus for two individual samples the proportion of all mRNA species that is GRP mRNA is 35 and $23 \%$.

\section{Discussion}

Previously we and others have reported the presence of a larger-than-expected GRP in the pregnant uterus of women and sheep (Giraud et al. 1996, Whitley et al. 1996, Xiao et al. 1996). Examination of the ovine molecule revealed several differences such as increased molecular weight and stability in plasma when compared with the well-known biologically active GRP1-27 and GRP18-27 (Giraud et al. 1996). In this study we sought to examine whether the larger-than-expected GRP was the product of a GRP-related gene or a product of alternative transcript arising from the GRP gene. Southern hybridisation of ovine genomic DNA fragments revealed several responsive bands that corresponded with the restriction pattern of the genomic fragments encompassing the ovine GRP gene. This result strongly suggested that the ovine genome possesses a single GRP or GRP-related gene. Nucleotide sequence analysis of three separate cDNA molecules isolated from an ovine endometrial cDNA library revealed some small differences to each other and to the previously published sequence (Fraser et al. 1994) in the $5^{\prime}$ and $3^{\prime}$ UTRs. However no differences were observed in the coding region and translation of any of these molecules would lead to a gene product predicted to be processed to GRP1-27 and GRP18-27. These results suggest that the larger-than-expected GRP observed in the pregnant uterus results from alternative processing of the GRP prohormone.

Normal processing of the GRP prepromolecule is similar to other neuropeptides and involves cotranslational cleavage of the signal peptide to yield proGRP which undergoes endoproteolytic cleavage at MGKK $\downarrow$ by an as yet uncharacterised prohormone convertase. Carboxypeptidase $\mathrm{E}$ removes the basic residues and peptidyl $\alpha-$ amidating mono-oxygenase acts on the glycine to yield C terminally amidated GRP1-27. Further endoproteolytic cleavage at Arg-17 within the motif KXXXR releases the decapeptide GRP18-27 (Bunnett 1994). For the larger-than-expected GRP to arise from alternative peptide processing, we predict an absence of the prohormone convertase activity at MGKK resulting in a C terminally extended form of GRP. This may result from lack of the enzyme in the pregnant uterine glandular epithelial cells or from a lack of access of the GRP processing convertase to the GRP prohormone perhaps coinciding with a switch from the regulated pathway to the constitutive pathway.

One possibility is that the larger-than-expected GRP observed in the pregnant ovine uterus is a usual intermediate in GRP prohormone processing. Comparison of the known mammalian proGRP amino acid sequences (Fig. 3) revealed two instances of the motif KXXXR. Processing at the first yields GRP $(18-27)$ while processing at the second KXXXR could produce cleavage at Lys- 45 to generate GRP1-44 from proGRP not cleaved at 


\section{A GRP mRnA (pg)}

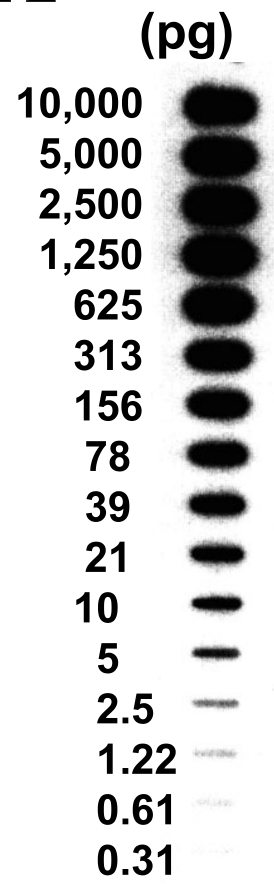

\section{B PolyA+ RNA (pg)}
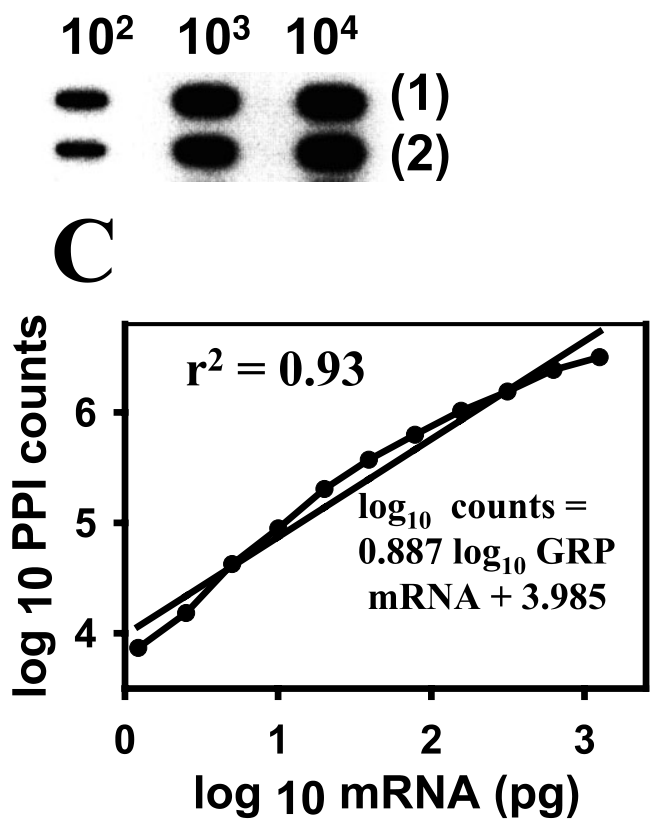

Figure 7 Quantification of GRP mRNA in RNA isolated from late term ovine pregnant endometrium. Phosphor image analysis of Northern hybridisation with radiolabelled antisense GRP riboprobe to (A) standards of membrane bound synthetic sense GRP RNA and to (B) double purified poly(A) + RNA isolated from two separate samples of late term pregnant endometrium. C, plot of linear range for $\log _{10}$ PPI counts versus $\log _{10}$ synthetic GRP RNA $(\bullet)$ and linear regression (straight line).

MGKK. This hypothesis is strengthened by the observation of a molecule of similar high molecular weight in the conditioned medium of the small cell lung carcinoma cell line NCI-H345 (Lebacq-Verheyden et al. 1988). In that study, several post-translation processing products of proGRP produced by the SCLC cell line NCI-H345 were identified including small amounts of amidated GRP1-27. The major secreted product was identified as a C terminally extended form of GRP1-27 ending at about Glu-40. Several other groups have reported the presence of $\mathrm{C}$ terminal extended forms of proGRP in SCLC tumours and cell lines (Holst et al. 1989, Vangsted \& Schwartz 1990). C terminal extended forms are biologically active (Mervic et al. 1991, Oiry et al. 2000)

In pregnant ovine endometrial cells, the very high abundance of GRP gene transcription could lead to the GRP processing and post-translational modifications being saturated so that partially processed product(s) become the major end product(s) and the amidated forms of GRP become minor end products. In the present study we determined the proportion of poly(A)+ RNA that is GRP mRNA to be 23 and $35 \%$ for two separate samples of late term pregnant ovine endometrium. Thus in this tissue, about one-third of all mRNA molecules are GRP
mRNA. We have previously shown, using in situ hybridisation, that only one cell type within ovine pregnant endometrium - the glandular epithelial cell - is responsible for GRP synthesis (Whitley et al. 1998). Accordingly within the glandular epithelial cells the proportion of all mRNA that is GRP mRNA would far exceed one-third. This is a truly remarkable abundance given that in most biological systems an mRNA species that constitutes $1 \%$ of the total pool is considered to be abundant and that the most abundant mRNA in the liver is albumin accounting for about 15\% (Anderson et al. 1997).

The observation of variation in the $5^{\prime}$ end of the cDNA molecules, and the strong correlation between the sequence and predicted promoter sites suggests that several different start sites may be used for transcription of the ovine GRP gene. This has been observed experimentally for the human GRP gene. In SCLC cell line NCI-H209 and normal fetal lung, transcription initiation was shown to start $25 \mathrm{nt}$ downstream from the TATA box with a minor start site $13 \mathrm{nt}$ downstream (Spindel et al. 1987). In a separate study, analysis by S1 nuclease protection and primer extension in two SCLC cell lines (NCI-H209 and NCI-H510) revealed a single transcription initiation start site at $32 \mathrm{nt}$ downstream of the TATA box (Markowitz 
et al. 1988). Computational analysis of the human GRP gene promoter using the neural network promoter prediction program predicts the start site at $11 \mathrm{nt}$ downstream from the TATA box. Alignment of approximately $300 \mathrm{nt}$ of ovine and human sequence surrounding the TATAA box of the GRP gene reveals extensive homology with similar positioning of the experimentally determined transcription initiation sites of human GRP gene and the predicted transcription initiation sites of the ovine GRP gene. Also found immediately upstream from the putative transcription initiation sites was a CRE site that was similarly positioned and identical in sequence to that observed in the human GRP gene (Nagalla \& Spindel 1994). However that study found only slight effects on GRP mRNA expression in SCLC cell lines in response to forskolin and dibutryl cAMP suggesting that this CRE site is unresponsive to CRE binding proteins or that the effect is masked by the action of other regulatory factors. In the present study, we determined the nucleotide sequence for $2200 \mathrm{bp}$ upstream of the putative transcription initiation sites as a starting point for functional analysis of the transcription factors responsible for the regulation of GRP mRNA expression.

Studies with GRP/bombesin and their antagonists have established a role for these peptides in normal fetal lung growth and maturation in a large variety of species including humans (Spindel et al. 1989, Sunday et al. 1990, Emanuel et al. 1999). GRP has been shown to be involved in differentiation of pulmonary neuroendocrine cells and is able to induce cell proliferation. In human, baboon, rhesus monkey and mice, peak GRP transcript levels occur during the canalicular phase of pulmonary development (Spindel et al. 1989, Sunday et al. 1990, Emanuel et al. 1999). This phase occurs around mid-gestation and is characterised by considerable extension and branching of the respiratory bronchioles and air-spaces with concomitant epithelialisation and capillary invasion (Reid 1984). In human fetal lung, this phase and GRP mRNA expression occur from approximately 16-30 week gestation (Spindel et al. 1989). In sheep fetal lung, the canalicular phase also occurs around mid-gestation the time when GRP mRNA expression was detected. The observation in the present study of two distinct periods of GRP mRNA expression (around days 60 and 140, term is 145 days) suggests that the fetal lung GRP also has distinct roles in lung branching morphogenesis (around mid-term) and in lung maturation (near parturition).

We used RT-PCR to examine the expression of GRP mRNA in tissue obtained from an ovine fetus at 120 days. Using this sensitive technique, expression of GRP mRNA was widespread occurring throughout the gastrointestinal tract (fundus, colon, jejunum, ileum, duodenum) and in various other tissues such as kidney, adrenal, lung, heart and pancreas. Very low expression was detected in the liver. No GRP mRNA expression was detected in 120 day fetal antrum in contrast to adult antrum where it has been demonstrated that GRP mRNA is produced by nerve fibres within the antral mucosa and circular muscle layer (Bunnett 1994). Radioimmunoassay of each of these fetal tissues (except adrenal) revealed the corresponding presence of GRP-ir. These findings suggest that GRP may act in a local manner for many fetal tissues, possibly as a morphogen, similar to the activity described in fetal lung above and as recently shown for mouse and human colon (Jensen et al. 2001). In the latter study, an identical transient pattern of GRP and GRP-R expression was observed in the developing human and mouse colonic villi during similar stages of gastrointestinal tract formation. Aberrant expression of growth factors during cancer often represents neo-expression of a fetal developmental phenotype as has been demonstrated for GRP expression in lung cancer and colon cancer (Sausville et al. 1986, Carroll et al. 1999).

The major conclusion of the present study is that the larger-than-expected GRP observed in ovine (and human) pregnant uterus does not arise from a distinct GRP-like gene or from alternative transcripts derived from the GRP gene. This leads us to the hypothesis that this form of GRP results from an alteration in processing of the GRP prohormone. We propose that the larger-thanexpected GRP molecule observed in the pregnant ovine endometrium represents a normal processing intermediate of proGRP and that this molecule becomes the major end product in pregnant ovine glandular epithelial cells. A similar observation has been made for prorenin which is the major end product of preprorenin processing in human utero-placental tissues in contrast to renal tissue where most prorenin is cleaved to renin (Poisner 1995). The mechanisms responsible for generation of the larger-thanexpected GRP in utero-placental tissues remain to be determined. Possibilities include the over-abundance of GRP mRNA and subsequent large amounts of prohormone exhausting the processing machinery, an absence or inaccessibility of specific processing enzymes or a redirection of synthesis down the constitutive pathway (denying access to secretory vesicles containing the appropriate proGRP prohormone convertase). These studies are in progress as are those exploring potential biological functions of the uterine predominant form of GRP.

\section{Acknowledgements}

Supported by the National Health and Medical Research Council of Australia and the Austin Hospital Research Foundation.

\section{References}

Anderson L \& Seilhamer J 1997 A comparison of selected mRNA and protein abundances in human liver. Electrophoresis 18 533-537. 
Ausubel FA, Brent R, Kingston RE, Moore DD, Seidman JG, Smith JA \& Struhl K (Eds) 2000 Current Protocols in Molecular Biology. New York: John Wiley \& Sons.

Bunnett N 1994 Gastrin-releasing peptide. In Gut Peptides: Biochemistry and Physiology, pp 423-445. Eds JH Walsh \& GJ Dockray. New York: Raven Press Ltd.

Carroll RE, Matkowskyj KA, Chakrabarti S, McDonald TJ \& Benya RV 1999 Aberrant expression of gastrin-releasing peptide and its receptor by well-differentiated colon cancers in humans. American Journal of Physiology 276 G655-G665.

Cuttitta F, Carney DN, Mulshine J, Moody TW, Fedorko J, Fischler A \& Minna JD 1985 Bombesin-like peptides can function as autocrine growth factors in human small cell lung cancer. Nature $316823-826$.

Emanuel RL, Torady JS, Mu Q, Asokananthan N, Sikorski KA \& Sunday ME 1999 Bombesin-like peptides and receptors in normal fetal baboon lung: roles in lung growth and maturation. American Journal of Physiology 21 L1003-L1017.

Fraser M, McDonald TJ, Spindel ER, Fahy M, Hill D \& Challis JR 1994 Gastrin-releasing peptide is produced in the pregnant ovine uterus. Endocrinology 135 2440-2445.

Giraud A, Parker L, Taupin D, Hardy K \& Shulkes A 1993 Mammalian bombesin as a hormone in ovine pregnancy: ontogeny, origin, and molecular forms. American Journal of Physiology $\mathbf{2 6 5}$ E866-E873.

Giraud A, Salamonsen L, Whitley J \& Shulkes A 1994 A peptide related to gastrin releasing peptide is synthesised and secreted by the ovine endometrium in early pregnancy. Endocrinology 135 2806-2809.

Giraud A, Whitley J, Shulkes A \& Parker L 1996 The pregnant ovine endometrium constitutively expresses and secretes a highly stable bombesin-like peptide, which shares C-terminal sequence but differs structurally from gastrin-releasing peptide. Biochimica et Biophysica Acta 1296 189-197.

Holst JJ, Hansen M, Bork E \& Schwartz TW 1989 Elevated plasma concentrations of C-flanking gastrin-releasing peptide in small-cell lung cancer. Journal of Clinical Oncology 7 1831-1837.

Jensen JA, Carroll RE \& Benya RV 2001 The case for gastrin-releasing peptide acting as a morphogen when it and its receptor are aberrantly expressed in cancer. Peptides 22 689-699.

Jurka J 1998 Repeats in genomic DNA: mining and meaning. Current Opinion in Structural Biology 8 333-337.

Lebacq-Verheyden AM, Kasprzyk PG, Raum MG, Van Wyke Coelingh K, Lebacq JA \& Battey JF 1988 Posttranslational processing of endogenous and of baculovirus-expressed human gastrin-releasing peptide precursor. Molecular and Cellular Biology 8 3129-3135.

Markowitz S, Krystal G, Lebacq-Verheyden A-M, Way J, Sausville EA \& Battey J 1988 Transcriptional activation and DNasI hypersensitive sites are associated with selective expression of the gastrin-releasing peptide gene. Journal of Clinical Investigation $\mathbf{8 2}$ 808-815.

Mervic M, Moody TW \& Komoriya A 1991 A structure function study of C-terminal extensions of bombesin. Peptides 12 1149-1151.

Nagalla SR \& Spindel ER 1994 Functional analysis of the 5'-flanking region of the human gastrin-releasing peptide gene in small cell lung carcinoma cell lines. Cancer Research 54 4461-4467.
Oiry C, Pannequin J, Bernad N, Artis AM, Galleyrand JC, Devin C, Cristau M, Fehrentz JA \& Martinez J 2000 A synthetic glycine-extended bombesin analogue interacts with the GRP/bombesin receptor. European Journal of Pharmacology 403 $17-25$.

Poisner AM 1995 Regulation of utero-placental prorenin. Advances in Experimental Medicine and Biology 377 411-426.

Reid LM 1984 Lung growth in health and disease. British Journal of Diseases of the Chest 78 113-134.

Sausville EA, Lebacq-Verheyden A-M, Spindel ER, Cuttitta F, Gazdar AF \& Battey JF 1986 Expression of the gastrin-releasing peptide gene in human small cell lung cancer. Journal of Biological Chemistry $2612451-2457$.

Spindel ER, Zilberberg MD, Habener JF \& Chin WW 1986 Two prohormones for gastrin-releasing peptide are encoded by two mRNAs differing by 19 nucleotides. PNAS 83 19-23.

Spindel ER, Zilberberg MD \& Chin WW 1987 Analysis of the gene and multiple mRNAs encoding human gastrin-releasing peptide: alternate RNA splicing occurs in neural and endocrine tissue. Molecular Endocrinology 1 224-232.

Spindel ER, Sunday ME, Hoflet H, Wolfe HJ, Habener JF \& Chin WW 1989 Transient elevation of messenger RNA encoding gastrin-releasing peptide, a putative pulmonary growth factor in human fetal lung. Journal of Clinical Investigation 80 1172-1179.

Sunday ME, Hua J, Dai HB, Nusrat A \& Torday JS 1990 Bombesin increases fetal lung growth and maturation in utero and in organ culture. American Journal of Respiratory Cell and Molecular Biology 3 199-205.

Vangsted AJ \& Schwartz TW 1990 Production of gastrin-releasing peptide-(18-27) and a stable fragment of its precursor in small cell lung carcinoma cells. Journal of Clinical Endocrinology and Metabolism 70 1586-1593.

Whitley JC, Giraud AS \& Shulkes A 1996 Expression of gastrinreleasing peptide (GRP) and GRP receptors in the pregnant human uterus at term. Journal of Clinical Endocrinology and Metabolism $\mathbf{8 1}$ 3944-3950.

Whitley JC, Shulkes A, Salamonsen LA, Vogiagis D, Familari M \& Giraud AS 1998 Temporal expression and cellular localization of a gastrin-releasing peptide-related gene in ovine uterus during the oestrous cycle and pregnancy. Journal of Endocrinology 157 139-148.

Whitley JC, Moore C, Giraud AS \& Shulkes A 1999 Molecular cloning, genomic organization and selective expression of bombesin receptor subtype 3 in the sheep hypothalamus and pituitary. Journal of Molecular Endocrinology 23 107-116.

Whitley JC, Giraud, AS, Mahoney AO, Clarke IJ \& Shulkes A 2000 Tissue-specific regulation of gastrin-releasing peptide synthesis, storage and secretion by oestrogen and progesterone. Journal of Endocrinology 166 649-658.

Xiao Q, Challis JR, Fraser M, Wlodek ME, Thorburn GD, Cuttita F, Hill DJ, St-Pierre S, Spindel ER \& McDonald TJ 1996 Locations and molecular forms of gastrin-releasing peptide immunoreactive entities in ovine pregnancy. Peptides 17 489-495.

Received 13 May 2002

Accepted 8 July 2002 